\title{
IDF Curves and Maximum Rainfall in 24 hours in the Subregions of La Mojana and San Jorge in Northern Colombia
}

\author{
Fernando Jove Wilches* ${ }^{* 1}$, Rodrigo Hernández Avila ${ }^{1}$ and Álvaro Rafael Caballero Guerrero ${ }^{2}$ \\ ${ }^{1}$ Department of Civil Engineering, Universidad de Sucre, Sincelejo, Sucre, Colombia. \\ ${ }^{2}$ Department of Civil and Environmental Engineering, Universidad del Norte, Barranquilla, Colombia.
}

ORCIDs: 0000-0002-2080-4036 (Fernando), 0000-0003-3178-8075 (Rodrigo), 0000-0002-3567-9135 (Álvaro)

\begin{abstract}
The viability of civil engineering projects depends to a great extent on the representative climatic conditions of the areas where the works are located. In this regard, the determination of the characteristic rainfall of the project area is of vital importance. From there it follows that a correct estimation and dimensioning of drainage systems and hydraulic structures, guarantees the operation and useful life of projects such as roads, airports, dams, bridges, urbanized areas and farming areas. The purpose of this document is to present a data set of maximum 24-hour precipitation and the elaboration of the IDF curves for all the active hydrological stations, located in two sub-regions to the south of the department of Sucre (north of Colombia); called the sub-region of La Mojana and the subregion of San Jorge. The geographical location of these territories and their proximity to three of the most important and mighty rivers in the country (Magdalena River, Cauca River and San Jorge River), make this area one of the most fertile in Colombia and with high potential to be a agricultural and agro-industrial pantry, being able to generate a great impact on the country's GDP. To obtain the precipitation data, the formal request procedure for precipitation data was followed before the Instituto de Hidrología, Meteorología y Estudios Ambientales (IDEAM) and for the elaboration of the IDF curves, the procedure recommended by the Instituto Nacional de Vias (INVIAS) was used, set out in its Manual de Drenaje de Carreteras. The set of precipitation data and IDF curves provides valuable information for future projects that are intended to be carried out within the Mojana and San Jorge subregions, as well as serving as a guide for the development of studies in other regions with similar hydrometeorological characteristics
\end{abstract}

Keywords: IDF curves, Rainfall, Maximum precipitation, Return period, Hydrological design.

\section{INTRODUCTION}

Rain is part of the hydrological process known as precipitation and can be expressed as a part of the amount of water that falls to the surface of the earth in a liquid state. Precipitation is one of the most important meteorological processes for Hydrology, which together with evaporation form the interaction of the atmosphere with the surface water present in the hydrological water cycle [1].
Precipitation can be characterized as a function of intensity, distribution in space-time and the frequency or probability of occurrence, from Curves Intensity - Duration - Frequency (IDF) [2]. Therefore, it is extremely important to have the IDF curves available that represent the hydrological conditions in the areas where the projects are developed. Unfortunately in many regions of Colombia, this information is not available.

The study of the temporal distribution of rainfall is of particular interest for different purposes, such as, for example, in the case of meteorological, edaphological and hydrological studies in which it is sought to provide indices to carry out flood studies or allow the feeding of precipitation models run off that allow improving the information available, for a correct design and dimensioning of civil works. For this purpose, knowledge of the precipitation intensities is required for different Return periods [3].

There are different techniques to describe the temporal structuring of rain or its temporal concentration within a given event. Among these, the use of Intensity-Duration-Frequency (IDF) curves stands out, through which it is intended to summarize the characteristics of a strong rain event during various time scales [4], [5].

The study area, due to its orographic conditions, is an area prone to flooding during certain times of the year, which has diminished its regional development. The data set was obtained from 15 meteorological stations located in the La Mojana and San Jorge areas. The series analyzed mostly cover a total of 42 years of observation, between 1975 and 2016, with the exception of three stations where their historical records archived at the Institute of Hydrology, Meteorology and Environmental Studies (IDEAM) were not available for the evaluated period.

The objective of this document was focused on the determination of the Intensity-Duration-Frequency (IDF) curves representative of the rainfall conditions of the municipalities located in the subregions of La Mojana and San Jorge in the department of Sucre, north of Colombia. To do this, it was required to know the behavior of rainfall from the pluviometry data provided, the purpose of which was to provide patterns of rainfall behavior with which the IDF curves were created that provide reliable and timely information to hydraulic engineers who intend to project hydraulic works within the area of influence of the area under study. 
International Journal of Engineering Research and Technology. ISSN 0974-3154, Volume 13, Number 10 (2020), pp. 2884-2894

(C) International Research Publication House. https://dx.doi.org/10.37624/IJERT/13.10.2020.2884-2894

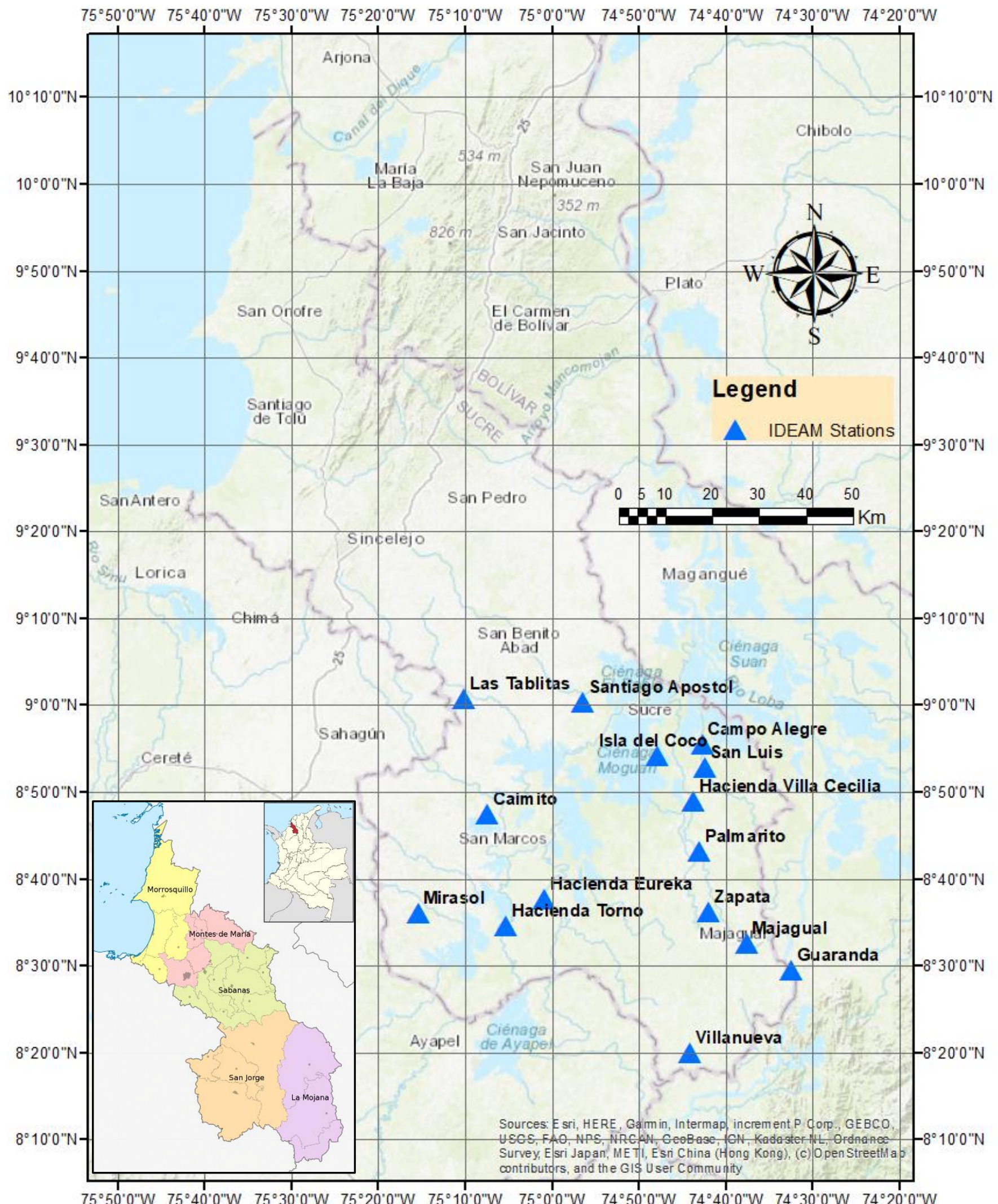

Fig. 1. Location of the meteorological stations belonging to the San Jorge and La Mojana area. 


\section{EXPERIMENTAL DESIGN, MATERIALS AND METHODS}

\section{II.I Study area description}

The Department of Sucre is located in the north of the country, in the Caribbean region, has an area of $10,670 \mathrm{~km}^{2}$ and is divided into five sub-regions. The La Mojana subregion is located in the extreme south of the department, it is made up of the municipalities of Sucre, Majagual and Guaranda, which together have an area of 2,337 $\mathrm{km}^{2}$. According to the dominant climatic variables, its climate is classified as tropical humid forest. Most of this territory corresponds to wetlands, made up of pipes, rivers, swamps and swamp forests, which are part of the Momposina Depression, an area that buffers and regulates the avenue of the Magdalena, Cauca and San Jorge rivers. The San Jorge subregion is located in the southwestern part of the department and is made up of the municipalities of San Marcos, San Benito Abad, La Unión and Caimito, which have a territory of $2,934 \mathrm{~km}^{2}$. It has areas of tropical humid forest, tropical dry forest, very dry tropical forest and natural savannas. Because they are located on the banks of the Rio San Jorge and next to the Mojana, they present hydrological similarities with the municipalities of this subregion [6].

\section{II.II Material and methods}

The development of the Intensity - Duration - Frequency (IDF) curves for the IDEAM meteorological stations, which are located in the Mojana and San Jorge subregions, were carried out through the procedure described in the Drainage Manual for Roads [7] of the National Highways Institute (INVIAS). In this section, the methodology used for the construction of the IDF curves is presented.

Through a request to IDEAM, the maximum daily 24-hour precipitation data was obtained for the 15 evaluated stations. The data provided correspond to historical series with monthly and annual frequencies, with records older than 25 years. The data was processed to start the process of elaboration of the curves.

In the first instance, the missing data of the information set was filled, for which the NIPALS (Nonlinear estimation by Iterative Partial Least Square) algorithm was applied, which is the basis of the PLS regression [8]. The algorithm iteratively applies principal component analysis to the data set with missing values. The main idea is to calculate the slope of the least squares line that crosses the origin of the observed data points and at the same time the algorithm can estimate the missing data [9]. During the research, the statistical software XLSTAT was used to generate the NIPALS algorithm in the data series with missing data, generating groups of stations with similar hydrological characteristics, in order to be able to obtain high correlation values between their variables.

Once the missing data had been filled in, tests of doubtful data (outliers) were carried out, using the Water Resources Council model to carry out adjustments of doubtful series that significantly deviate from the trend of the information, which can affect in a considerable way the magnitude of the statistical parameters of the series. These tests are recommended to detect the points that are separated from the maximum values above and below, and thus make the decision to preserve or eliminate data that may affect the magnitude of the statistical parameters [10], with a level of significance $10 \%$.

Table 1. General data and location of meteorological stations

\begin{tabular}{|c|c|c|c|c|c|c|}
\hline \multirow{2}{*}{$\begin{array}{l}\text { Station Name } \\
\text { Villanueva }\end{array}$} & \multirow{2}{*}{$\begin{array}{l}\text { Station ID } \\
25020940\end{array}$} & \multicolumn{2}{|c|}{$\begin{array}{c}\text { Coordinates } \\
\text { (Latitude / Longitude) }\end{array}$} & \multirow{2}{*}{$\begin{array}{c}\begin{array}{c}\text { Elevation } \\
(\mathbf{m})\end{array} \\
45\end{array}$} & \multirow{2}{*}{$\begin{array}{l}\text { Region } \\
\text { Sucre }\end{array}$} & \multirow{2}{*}{$\begin{array}{l}\text { Municipality } \\
\text { Guaranda }\end{array}$} \\
\hline & & 8.33277778 & -74.7355556 & & & \\
\hline Guaranda & 25020350 & 8.49277778 & -74.5416667 & 30 & Sucre & Guaranda \\
\hline Majagual & 25025240 & 8.54269444 & -74.6273333 & 26 & Sucre & Majagual \\
\hline Zapata & 25020820 & 8.60277778 & -74.6997222 & 50 & Sucre & Majagual \\
\hline Palmarito & 25020790 & 8.71888889 & -74.7177778 & 50 & Sucre & Majagual \\
\hline Hda. Villa Cecilia & 25020500 & 8.81611111 & -74.7294444 & 50 & Sucre & Sucre (Sucre) \\
\hline San Luis & 25021370 & 8.88166667 & -74.7080556 & 20 & Sucre & Sucre (Sucre) \\
\hline Isla del Coco & 25021560 & 8.90277778 & -74.7986111 & 20 & Sucre & Sucre (Sucre) \\
\hline Campo Alegre & 25021360 & 8.92472222 & -74.7119444 & 20 & Sucre & Sucre (Sucre) \\
\hline Hacienda Torno & 25021470 & 8.57638889 & -75.0897222 & 60 & Sucre & San Marcos \\
\hline Hacienda Eureka & 25020740 & 8.62916667 & -75.0147222 & 20 & Sucre & San Marcos \\
\hline Mirasol & 25021660 & 8.60083333 & -75.2572222 & 30 & Sucre & San Marcos \\
\hline Caimito & 25020980 & 8.79083333 & -75.1244444 & 20 & Sucre & Caimito \\
\hline Santiago Apóstol & 25020760 & 9.00472222 & -74.9405556 & 25 & Sucre & San Benito Abad \\
\hline Las Tablitas & 25020750 & 9.01138889 & -75.1688889 & 60 & Sucre & San Benito Abad \\
\hline
\end{tabular}


Next, a probabilistic distribution analysis was performed with the data set, for which the Gumbel, log-Gumbel, Pearson type III and log-Pearson type III distribution were used [11]. After carrying out the frequency analyzes of the hydrological information of the maximum 24-hour precipitation, the Gumbel distribution was chosen, which presented the best fit for the dataset. The highest value for each year of the monthly data was selected for each station and a table of maximum rainfall 24 hours with annual frequency was constructed.

Then, based on the precipitation values obtained in the previous step, the annual average maximum precipitation in $24 \mathrm{~h}$ at a multi-year level (M) was determined for each of the stations; Equation (1) [7], [12] can be applied to calculate the intensity:

$$
i=\frac{a \cdot T^{b} \cdot M^{d}}{(t / 60)^{c}}
$$

Where $\mathrm{i}$, is the precipitation intensity $(\mathrm{mm} / \mathrm{hr})$ that is required to be calculated for the construction of the IDF curves and the constants a, b, c and d are adjustment coefficients according to the region in which the evaluated station is located [12].

By varying the values of the return period $(\mathrm{T})$ and the duration of the rain in minutes $(\mathrm{t})$, the tables are constructed, and then plotted using the Excel spreadsheet and obtaining the I-D-F curves.

Table 2. Maximum 24-hour rainfall values of the stations during the study period

\begin{tabular}{|c|c|c|c|c|c|c|}
\hline \multirow{2}{*}{ Station Name } & \multirow{2}{*}{ Code } & \multicolumn{2}{|c|}{ Measurement Period } & \multicolumn{2}{|c|}{ Precipitation Values (mm) } & \multirow{2}{*}{$\begin{array}{l}\text { Average Maximum } \\
\text { 24-hour Rainfall (mm) }\end{array}$} \\
\hline & & (Start Year & / End Year) & (Minimum / & Maximum) & \\
\hline Villanueva & VIL & 1975 & 2016 & 83 & 235 & 154.2 \\
\hline Guaranda & GUA & 1975 & 2016 & 90 & 250 & 144.6 \\
\hline Majagual & MAJ & 1975 & 2016 & 74 & 158 & 122.7 \\
\hline Zapata & ZAP & 1975 & 2016 & 75 & 175 & 125.9 \\
\hline Palmarito & PAL & 1975 & 2016 & 50 & 160 & 107.9 \\
\hline Hda. Villa Cecilia & VCE & 1975 & 2016 & 62 & 204 & 118.2 \\
\hline San Luis & SLU & 1977 & 2016 & 70 & 150 & 117.1 \\
\hline Isla del Coco & $\mathrm{ICO}$ & 1975 & 2016 & 51 & 160 & 104.5 \\
\hline Campo Alegre & CAL & 1975 & 2016 & 73 & 174 & 113.8 \\
\hline Hacienda Torno & HTO & 1983 & 2014 & 65 & 155 & 113.0 \\
\hline Hacienda Eureka & HEU & 1975 & 2016 & 62 & 180 & 108.8 \\
\hline Mirasol & MIR & 1991 & 2016 & 48 & 144 & 97.0 \\
\hline Caimito & CAI & 1975 & 2016 & 64 & 145 & 96.4 \\
\hline Santiago Apóstol & SAP & 1975 & 2016 & 60 & 141 & 100.4 \\
\hline Las Tablitas & TAB & 1975 & 2016 & 55 & 160 & 93.4 \\
\hline
\end{tabular}

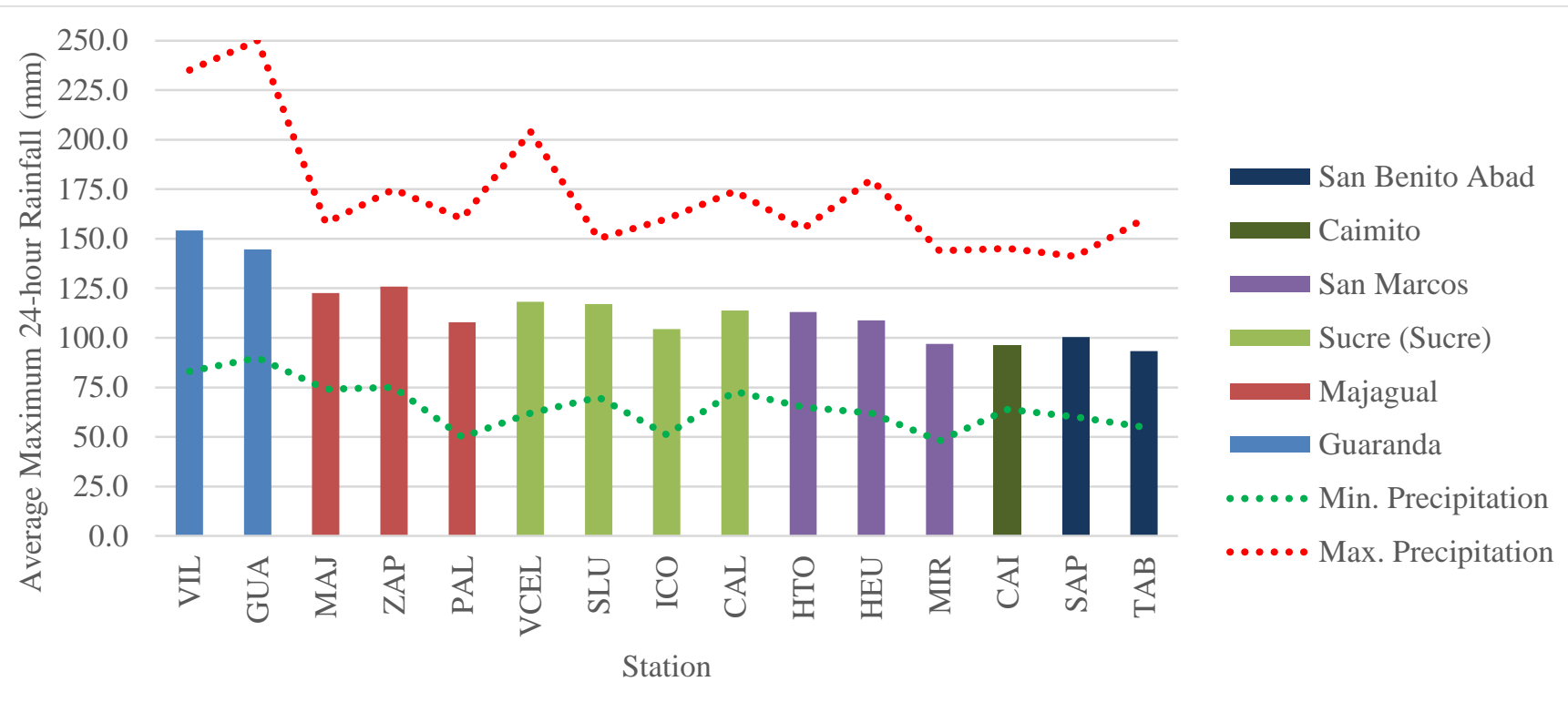

Fig. 2. Average, minimum and maximum values for maximum 24-hour rainfall for each station 
International Journal of Engineering Research and Technology. ISSN 0974-3154, Volume 13, Number 10 (2020), pp. 2884-2894

(C) International Research Publication House. https://dx.doi.org/10.37624/IJERT/13.10.2020.2884-2894

\section{RESULTS}

The results presented below have been elaborated from the analyzed data of the maximum 24-hour rainfall from 15 meteorological stations, located south of the department of Sucre (Colombia). Table 1 presents the name and ID code provided by IDEAM of the 15 stations selected for this study. Additionally, the coordinates and elevation of each of the stations were added, as well as the Region and the municipality to which each station belongs. Information about the rainfall of the stations in question can be seen in Table 2. Fig. 2 shows the number of active meteorological stations, broken down by geographic subregion and by municipality. Fig. 3 shows information about the maximum rainfall 24 hours averages for each Station, additionally the minimum and maximum precipitation curves with dotted lines were added.

Figures 3, $4,5,6,7$ and 8 shows the I-D-F curves corresponding to the Meteorological Stations located in the municipalities of Guaranda, Majagual, Sucre, San Marcos, Caimito and San Benito Abad belonging to the La Mojana and San Jorge subregion.

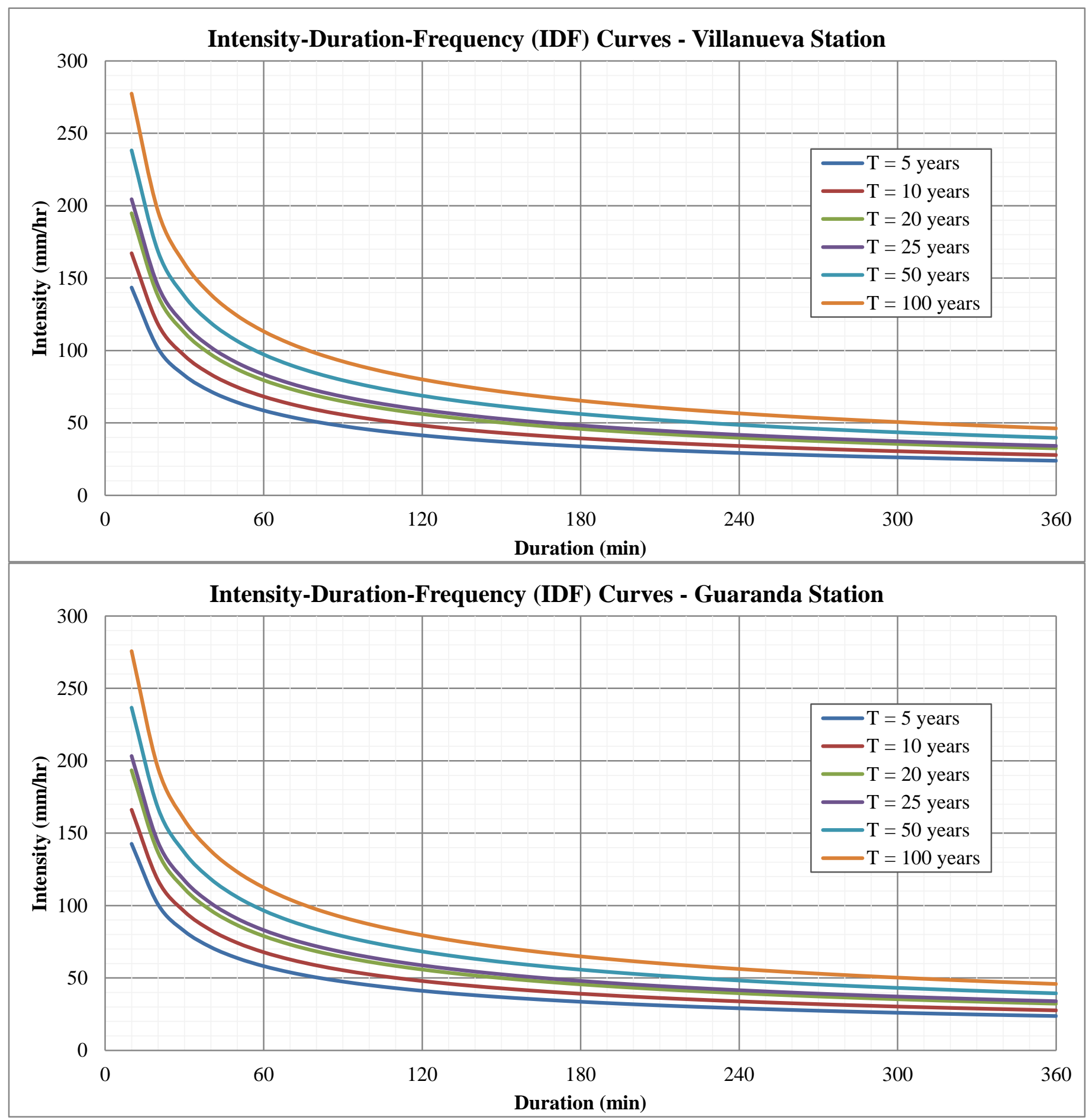

Fig. 3. Intensity-Duration-Frequency (IDF) curves for VIL and GUA stations 

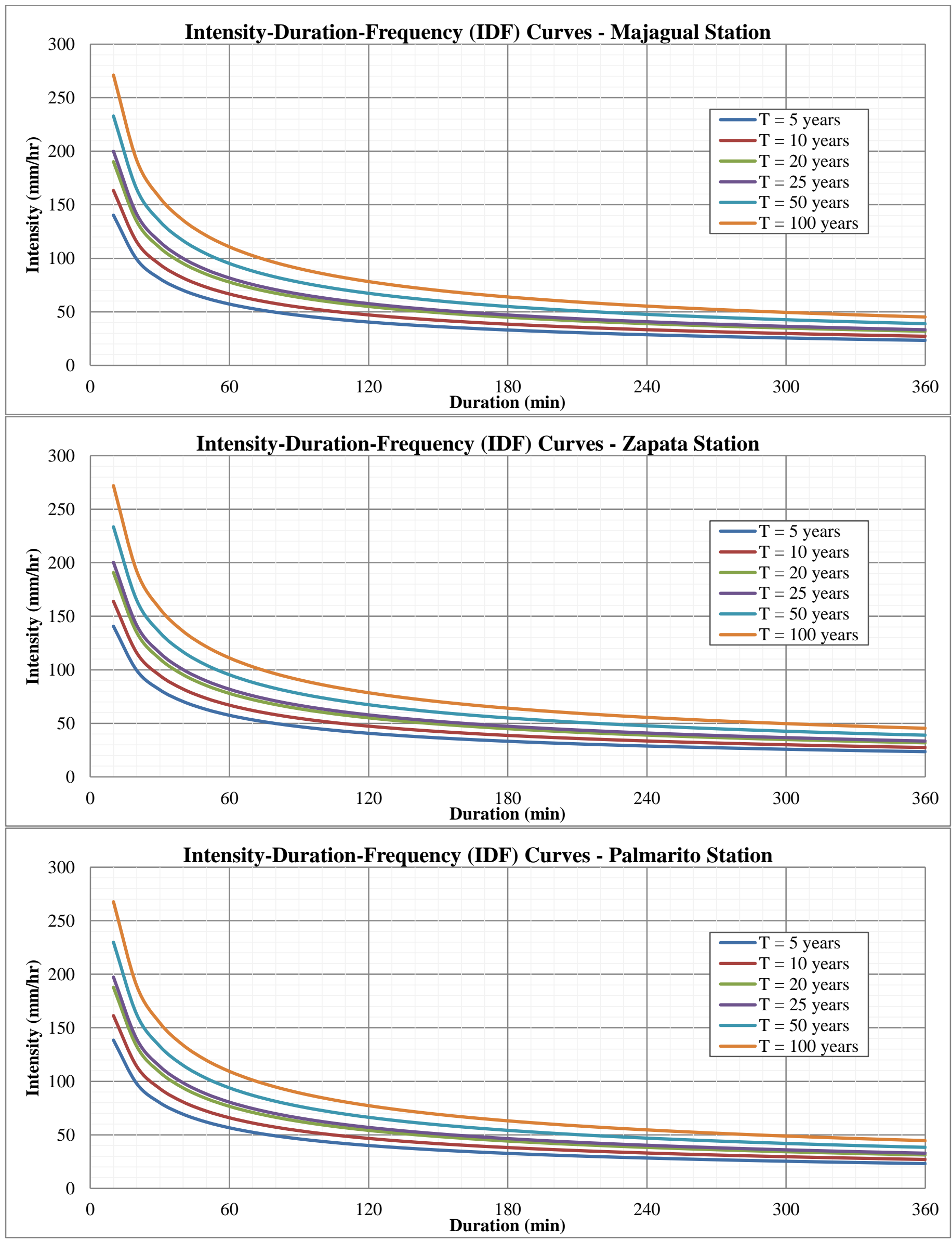

Fig. 4. Intensity-Duration-Frequency (IDF) curves for MAJ, ZAP and PAL stations 

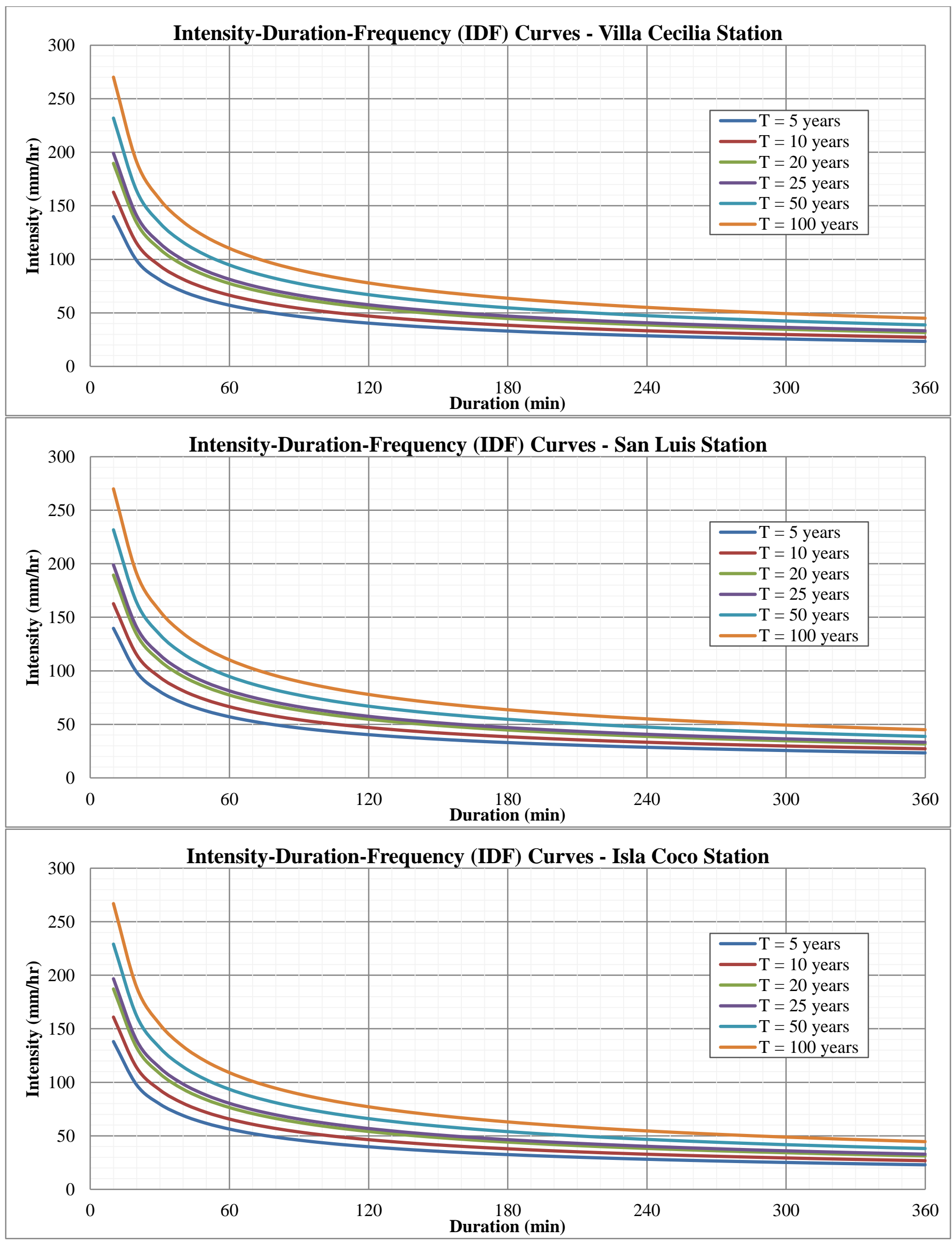

Fig. 5. Intensity-Duration-Frequency (IDF) curves for VCE, SLU and ICO stations 

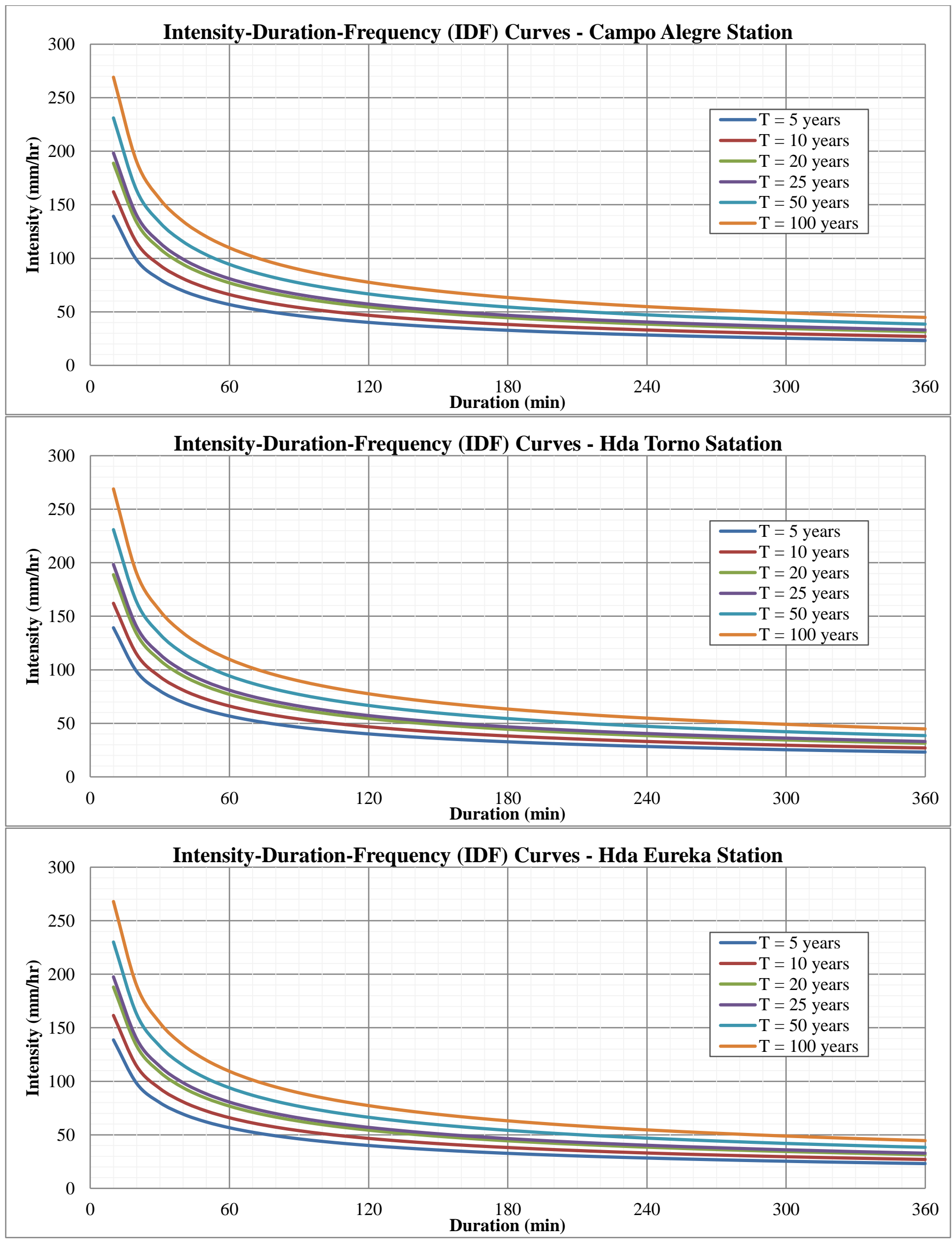

Fig. 6. Intensity-Duration-Frequency (IDF) curves for CAL, HTO and HEU stations 

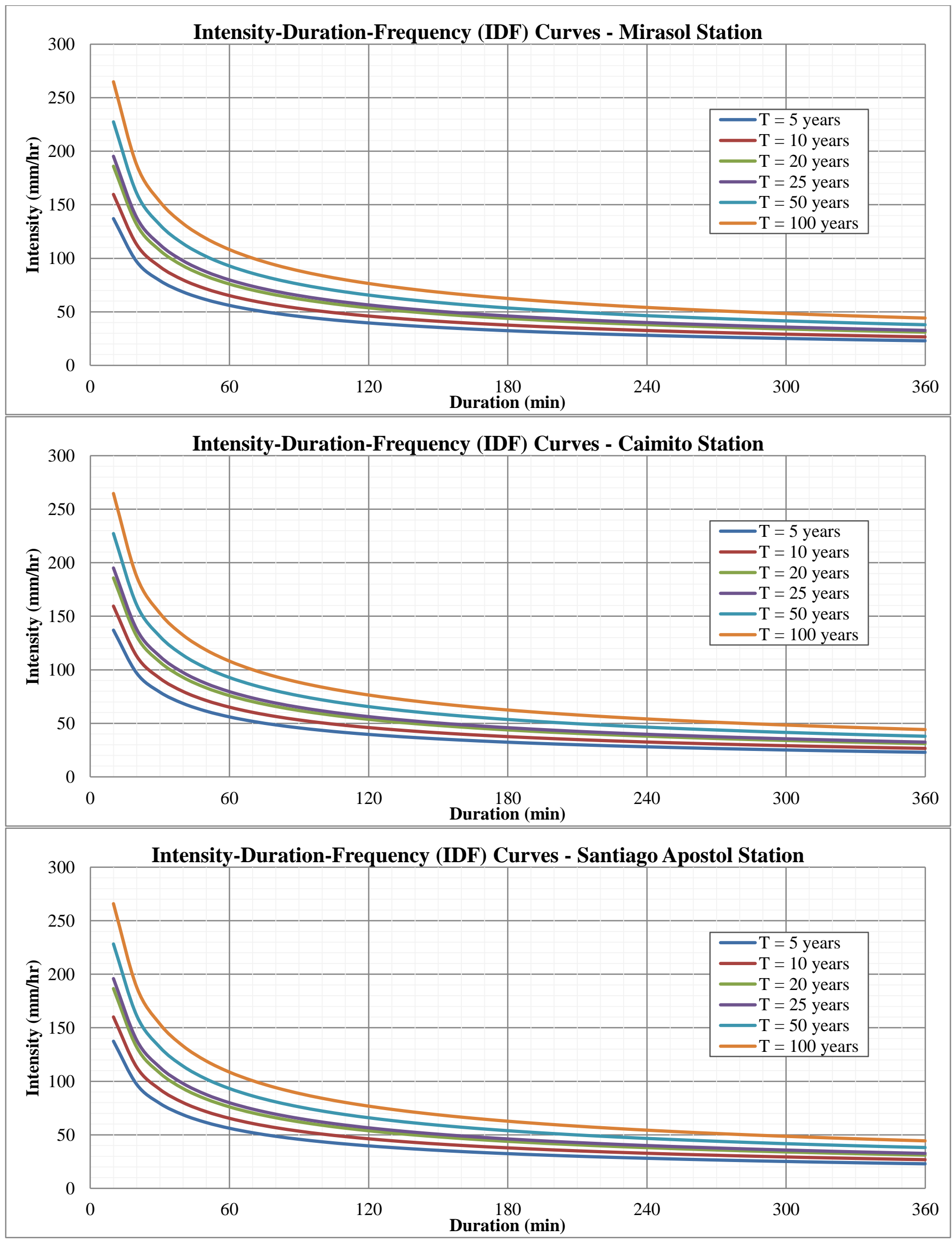

Fig. 7. Intensity-Duration-Frequency (IDF) curves for MIR, CAI and SAP stations 


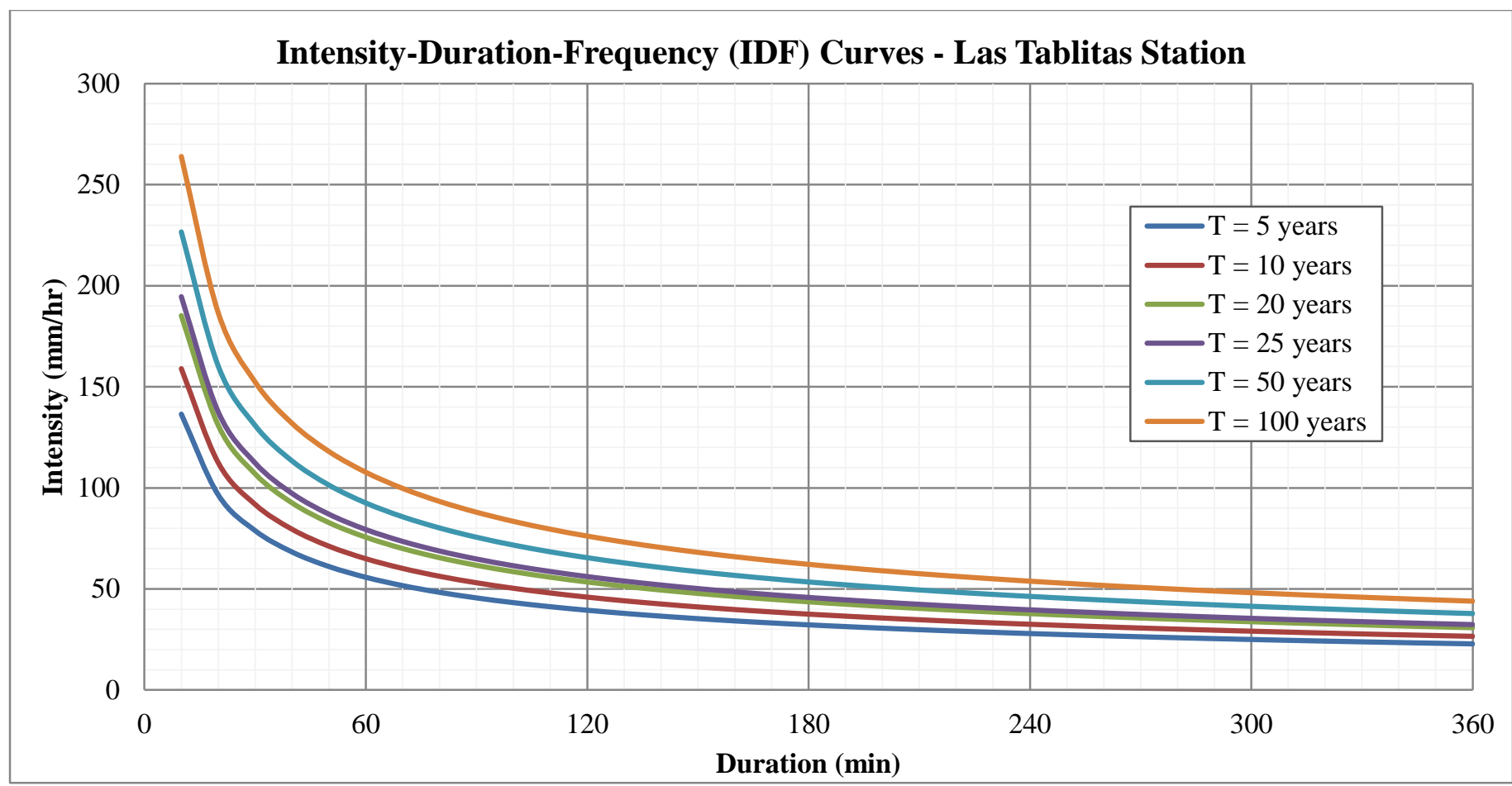

Fig. 8. Intensity-Duration-Frequency (IDF) curves for TAB station

\section{CONCLUSIONS}

According to the results obtained, it was established that the municipalities located in the La Mojana subregion have higher rainfall than those located in the San Jorge subregion, with maximum rainfall values for 24 hours of up to $250 \mathrm{~mm}$.

It was possible to obtain the I-D-F- curves representative of the rainfall conditions of the municipalities located in two of the most important geographical subregions of the department of Sucre.

\section{Acknowledgments}

The authors thank the engineer Edilberto Elias Contreras Sierra for the contributions made in the development of the manuscript.

\section{REFERENCES}

[1] Garcia G. Modelo de pérdidas para determinar precipitación efectiva usando sistemas de información geográfica. Tesis. Universidad de Piura. 2004. Recovered from http://www.biblioteca.udep.edu.pe/bibvirudep /tesis/pdf/1_136_147_89_1250.pdf

[2] Pérez J, Senent J. Curvas Intensidad-DuraciónFrecuencia de tormentas de corta duración en la cuenca del río Segura, España. Agrociencia, 2017;51(6):607616. Recovered from Error! Hyperlink reference not valid.

[3] Pizarro R, Pizarro JP. Sangüesa C. Martínez E. Módulo 2: Curvas Intensidad Duración Frecuencia (pdf).
Sociendad Estándares de Ingeniería para Aguas y Suelos LTDA.

[4] Monjo R. Measure of rainfall time structure using the dimensionless n-index. Climate Research, 2016;67: 7186. DOI: $10.3354 / \mathrm{cr} 01359$

[5] Moncho R, Belda F, Caselles V. Climatic study of the exponent "n" in IDF curves: application for the Iberian Peninsula Archivado el 1 de enero de 2011 en la Wayback Machine. (pdf). Tethys, 2009; 6:3-14. DOI: 10.3369/tethys.2009.6.01.

[6] Colombia Aprende, Plan de Educación Rural del Departamento de Sucre (2012). http://aprende.colombiaaprende.edu.co/ckfinder/userfiles /files/PER\%20SUCRE\%202011.pdf (accesed 24 July 2020).

[7] Instituto Nacional de Vías, Manual de Drenaje para Carreteras, Ministerio de Transporte, Bogotá, Colombia, 2009.

[8] Wold H. Nonlinear Estimation by Iterative Least Square Procedures. In: Research Papers in Statistics (F. David, ed.), Wiley, New York, pp. 411-444, 1966.

[9] Sattari MT, Rezazadeh-Joudi A, Kusiak A. Assessment of different methods for estimation of missing data in precipitation studies, Hydrology Research. 2017; 48(4): 1032-1044.DOI: https://doi.org/10.2166/nh.2016.364

[10] Chow VT, Maidment DR, Mays LW. Applied Hydrology, International Edition, McGraw-Hill, Civil Engineering Series, New York, 1988. 
International Journal of Engineering Research and Technology. ISSN 0974-3154, Volume 13, Number 10 (2020), pp. 2884-2894

(C) International Research Publication House. https://dx.doi.org/10.37624/IJERT/13.10.2020.2884-2894

[11] Monsalve G. Hidrología en la Ingeniería, Segunda Edición, Editorial Escuela Colombiana de Ingeniería, Bogotá D.C., Colombia, 1999.

[12] Vargas R, Díaz M. Curvas Sintéticas Regionalizadas de Intensidad-Duración-Frecuencia para Colombia, Universidad de los Andes, Santafé de Bogotá, 1998. 